\title{
Locally Advanced Pancreatic Ductal Adenocarcinoma
}

National Cancer Institute

\section{Source}

National Cancer Institute. Locally Advanced Pancreatic Ductal Adenocarcinoma. NCI

Thesaurus. Code C151993.

A pancreatic ductal adenocarcinoma that has spread from its original site of growth to nearby tissues or lymph nodes. 